\title{
Philosophy, Religion, and Heterodoxy in the Philosophy of Henry More, Ralph Cudworth, and Anne Conway
}

\author{
Sarah Hutton \\ University of York, York, U K \\ sarah.hutton@york.ac.uk
}

\begin{abstract}
Philosophers who hold the compatibility of reason and faith, are vulnerable to the charge of opening the way to atheism and heterodoxy. This danger was particularly acute when, in the wake of Cartesianism, the philosophy of Spinoza and Hobbes necessitated a resetting of the relationship of philosophy with religion. My paper discusses three English philosophers who illustrate the difficulties for the philosophical defence for religion: Henry More, Ralph Cudworth, and Anne Conway, for all of whom philosophical and religious truth were deeply intertwined. But each of them also subscribed to heterodox religious beliefs. This raises questions of whether there is a direct the relationship between their philosophy and religious heterodoxy — whether they exemplify the charge that philosophy undermines religion, or indeed whether their defence of religion was a cover for heterodoxy.
\end{abstract}

\section{Keywords}

atheism - heterodoxy - Platonism - Descartes - More - Cudworth - Conway

\section{Introduction}

Accusations of atheism occur relatively frequently in the philosophico-theological polemics of the seventeenth century. ${ }^{1}$ This is particularly the case with

1 The term "atheism" itself had broader sense than it does today as a blanket term for irreligion 
Hobbes and Spinoza, but Cartesianism was seen by many as leading to atheism. In England, the perceived dangers posed by reason for religion were held to be exemplified by the free thinkers known as Deists. Although denounced as atheists by their detractors, the Deists were all pre-occupied with religion, but in unorthodox ways. They shocked because of their preparedness to treat Christianity as natural rather than revealed religion. In the eyes of their detractors the materialist and sceptical tendencies of the freethinkers were symptomatic of the danger which their philosophical views posed for religion. One of the first to be graced with the name of Deist, Herbert of Cherbury, ${ }^{2}$ attempted to base religion on the truths of reason. Herbert never denied the existence of God, but this move was profoundly heterodox, as were the conclusions he drew on the basis of his rational treatment of religion, including his denial of absolute reprobation and his hope for universal salvation. Later deists drew inspiration from Locke. Anthony Collins, for example, went beyond Locke by advancing a materialist account of consciousness in his Discourse of Freethinking (1713). John Tindal's Christianity as Old as the Creation (1730) outlines a religion based on the law of nature which is synonymous with reason. The most notorious freethinker was John Toland, whose Christianity not Mysterious (1696) was condemned to be publicly burned in Dublin in 1697. But they were not the only philosophers to hold theological views of dubious orthodoxy, for example John Locke was suspected of anti-Trinitarianism, as was Samuel Clarke whose philosophical defence of religion went hand in hand with denial of the Trinity.

The incidence of religious heterodoxy among philosophers invites the question whether there is a direct relationship between philosophy and religious heterodoxy and atheism: do they exemplify the charge that philosophy undermines religion? Was it their philosophy which eroded their religious credentials (as their enemies claimed), or was it their heterodox religious beliefs which lead them to philosophise in the way they did? One might go further, and ask whether those philosophers who critiqued other philosophers as atheistic were consciously trying to conceal or protect their actual beliefs, whether, indeed, their defence of religion more generally was a decoy designed to distract from their own suspect views. It was, for instance, reported by William Warburton about Ralph Cudworth, that, "under the pretence of defending Revelation, he

in general. See Michael Hunter, “The Problem of 'Atheism' in Early Modern England," Transactions of the Royal Historical Society 35 (1985), 135-157. See also Michael Hunter and David Wootton, eds., Atheism from the Reformation to the Enlightenment (Oxford, 1992).

2 Herbert was attacked as a Deist by Christian Kortholt (De tribus impostoribus magnis, 1680), Michael Berns (Alter der Atheïsten, der Heyden, und der Christen, 1692), Thomas Halyburton (Natural Religion insufficient, 1714), and Philip Skelton (Ophiomaches: or, Deism revealed, 1749). 
wrote in the very manner that an artful infidel might naturally be supposed to use in writing against it ... in a word, he was an atheist in his heart and an Arian in his book".3 I doubt whether we can answer these questions with any certainty. I propose to explore this a bit further by examining the group of philosophers for whom philosophical and religious truth were deeply intertwined and who assumed the compatibility of reason and faith: Henry More, Ralph Cudworth and Anne Conway, all of whom held heterodox views.

\section{$2 \quad$ Heterodoxy and Atheism}

Although accusations of atheism were freely bandied about in seventeenthcentury theologico-philosophical polemics, more discriminating apologists for religion distinguish between atheism and heterodoxy, i.e., wrong belief, or misbelief rather than unbelief. This is a point made by Ralph Cudworth when defending his apologetic strategy in his True Intellectual System of the Universe (1678). The book, he tells his readers in the Preface, is directed not just at atheists, but, more importantly, at wavering or mistaken theists.

[T] his Labour of ours, is not Intended only for the Conversion of Downright and Professed Atheists, (of which there is but Little Hope, they being sunk into so great a degree of Sottishness;) but for the Confirmation of Weak, Staggering, and Scepticall Theists.

This group of luke-warm believers was a just as much of a problem as atheism; consequently, those who attack atheism (the "Exploders of Atheists," as Cudworth calls them)

must needs Grant, such Endeavours as these [i.e. Cudworth's book], for the Confirming and Establishing of mens Minds in the Belief of a God, by Philosophick Reasons, in an Age so Philosophicall, not to be Superfluous and Useless. ${ }^{4}$

As Cudworth recognised, those who sought to defend religion by philosophical means faced the apologist's dilemma: on the one hand believers do not need

3 Warburton, The Divine Legation of Moses, cited by Birch in Cudworth, The True Intellectual System (London: J. Walthoe et al., 1743), xiii.

4 Ralph Cudworth, The True Intellectual System of the Universe (London: Richard Royston, 1678), sig.*** $2 \mathrm{v}$ (hereafter cited as $T I S$ ). 
philosophy in order to be convinced of the existence of God; on the other hand mathematical logic alone is insufficient to convince unbelievers of the existence of God. But in between there is a middle ground of those who still have some belief in a deity. These lukewarm believers might be persuaded by rational argument to confirm their theism, or to abandon it. And they are more likely to be persuaded one way or the other if they are presented with strong reasoning. Dealing with heterodoxy rather than atheism or complete scepticism sets the onus of proof lower, since the parties agree on religion. But it nonetheless introduces the problem, that if the veracity of revelation can be demonstrated rationally, and indeed if saving truth is demonstrable by reason, revelation is not essential to salvation. Even when religious rationalism does not go that far, to rely on reason in religion risks a drift towards Deism or Socinianism. ${ }^{5}$ The worry for theists was that heterodoxy is a slippery slope towards atheism. The slippage between heresy, heterodoxy, and atheism is captured by Cudworth's daughter, Damaris Masham, in her light-hearted account of how the thinking (Christian) woman risks being viewed, whose

understanding of the Christian Religion would go nearer to render her suspected of Heresy even by those who thought the best of her: while her little zeal for any Sect or Party would make the Clergy of all sorts give her out for a Socinian or a Deist: And should but a very little Philosophy be added to her other Knowledge, even for an Atheist. ${ }^{6}$

That heterodoxy is conducive to atheism is aptly illustrated in the dispute which erupted later (1704) between Jean Le Clerc and Pierre Bayle regarding Cudworth's philosophy. ${ }^{7}$ Bayle charged that Cudworth's conception of Plastic Nature opened the door to atheism by rendering God superfluous since Bayle took Plastic Nature to be an entity operating independently of God. ${ }^{8}$ In the

5 See Martin Mulsow and Jan Rohls, eds., Socinianism and Arminianism: Antitrinitarians, Calvinists and Cultural Exchange in Seventeenth-century Europe (Leiden, 2005).

6 Damaris Masham, Occasional Thoughts in Reference to a Virtuous or Christian Life (London: A. and J. Churchil, 1705), 199.

7 Luisa Simonutti, "Bayle and Leclerc as Readers of Cudworth. Elements of the Debates on Plastic Nature in Dutch Learned Journals," Geschiedenis van de Wijsbegeerte in Nederland 40 (1993), 147-165; Susan Rosa, "Ralph Cudworth in the République des Lettres: The Controversy about Plastick Nature and the Reputation of Pierre Bayle," Studies in Eighteenth-Century Culture 23 (1994), 157-16o.

8 Bayle's critique of Cudworth originally appeared in Basnage de Beauval's Histoire des Ouvrages des Savants and his own Continuation des pensées diverses sur la comète, republished in his CEuvres Diverses (The Hague: P. Husson et al., 1727). 
ensuing controversy with Le Clerc, which was conducted in the pages of Le Clerc's Bibliotheque choisie and Bayle's Continuation des pensées diverses sur la comète and his Réponses aux questions d'un provinçal, Bayle accused Le Clerc of Socinianism, and Le Clerc in his turn accused Bayle of behaviour unbecoming to a Protestant, and of succouring atheism with his radical fideism. At its basis, this dispute between Bayle and Le Clerc, was not a case of believer versus atheist or libertines, but of a quarrel between two Christian philosophers committed to the same beliefs: the existence of God and the truth of the Christian religion. But it highlighted rather different conceptions of God, God's relationship to the world, and the relationship of reason to faith. Although Bayle charged that Cudworth's philosophical concept of Plastic Nature tended to atheism, the dispute between Le Clerc and Bayle was not a quarrel between theism and atheism, but between one version of orthodox religious belief and another. Strictly, what each stood for, from the perspective of the other's beliefs, was heterodoxy, not atheism, since neither charged the other with denying the existence of God. But in the heat of polemics, the heterodoxy of the opponent was treated as conducive to atheism. And this, of course, was Bayle's charge against Cudworth - that he was not an atheist, but that his philosophical theories (in particular his conception of Plastic Nature), was conducive to atheism. In this respect, heterodoxy becomes potential atheism. The dispute illustrates the trap for philosophers who tangle with religion: they risk becoming entangled in disputes in theology and over creed.

\section{$3 \quad$ Natural Theology}

Leaving aside the complexities of Bayle's own position with regard to religion, it by no means followed that reason was universally held to be antithetical to religious belief. In fact the compatibility of reason and faith was enshrined in a long standing tradition within the universities, which accorded philosophy the role of ancilla theologiae or the 'handmaid' of theology. ${ }^{9}$ Philosophy was studied in the universities as propaedeutic to theology, playing a key role in natural theology in which students were taught ways of discussing theology rationally, and how far religion may be demonstrable by natural light. Henry More refers to this apologetic, or defensive role of philosophy when announcing the apologetic aim of his philosophical writings: "My Designe," he writes, in

9 Scott Mandelbrote, "Early Modern Natural Theologies," in The Oxford Handbook of Natural Theology, ed. R.R Manning et al. (Oxford, 2013), 76-96. 
the Preface to his A Collection of Several Philosophical Writings, "is not to Theologize in Philosophy, but to draw an Exoterick Fence or exteriour Fortification about Theologie."10

Although there were differences of view on the extent to which reason might serve as a guide in religious matters, the repertoire of sources for natural theology included arguments from classical texts like Cicero's De natura deorum, as well as arguments developed by scholastic theologians. With the demise of the old Aristotelian-scholastic framework, new arguments were required. Initially, Cartesianism appeared attractive to many as a new basis for defending the truth of religion, especially in what Ralph Cudworth called "an age so philosophical."11 Like many others, both More and Cudworth embraced it as the best instrument for confirming the existence of God and of immaterial souls. But it soon became apparent that Cartesianism had its limitations for the purposes of natural theology. More, who saw himself as a proponent of natural religion, someone "who have been from my youth to this very day, so open a stickler for the support of natural religion, and for Christianity itself," came to consider, "how prejudicial Des Cartes's mechanical pretensions are to the belief of a God." 2 The radical resetting of the relationship of philosophy and religion by Spinoza and Hobbes exacerbated fears that philosophy was the progenitor of atheism and irreligion. As More saw it, the high road to Spinoza's atheism lay through Cartesianism: "Spinosa, a Jew first, after a Cartesian, and now an atheist." 13 So the very real threat that atheistic conclusions could result from rational analysis of religious matters posed problems for those who held the compatibility of reason and faith, who were especially vulnerable to charges of opening the way to heterodoxy and thence to atheism.

Although they all drew on Platonism, More, Cudworth, and Conway were all beneficiaries of the Cartesian turn in philosophy. More was one of the first Englishmen to advocate teaching Cartesian philosophy in universities, and he introduced Anne Conway to the study of philosophy using Descartes. Cudworth was thoroughly steeped in the philosophy of Descartes whom he admired as "an Acute Philosopher."14 Although they all held that religious truth

\footnotetext{
10 More, A Collection of Several Philosophical Writings (London: James Flesher, 1662) (hereafter cited as $C S P W)$, Preface General, vi). Cudworth, TIS (see above n. 4), sig.***2v.

12 "Henry More to Robert Boyle" in The Conway Letters: The Correspondence of Anne, Viscountess Conway, Henry More, and their Friends: 1642-1684, ed. Marjorie Hope Nicolson and revised by Sarah Hutton (Oxford, 1992), 519.

13 Ibid

14 Cudworth, TIS (see above n. 4), 646. Cudworth is an important figure in the English recep-
} 
could be defended philosophically, in their individual religious beliefs, all three departed from orthodoxy: Henry More subscribed to the theologically heterodox doctrine of the pre-existence of souls, Ralph Cudworth to a Platonically inspired subordinationist account of the Trinity, while Anne Conway denied the existence of hell and subscribed to the doctrine of apocatastasis, or universal salvation.

In the Christian tradition, to draw on Platonism had its drawbacks, given the negative associations of Platonism with Trinitarian heresies after the Council of Nicea, when Platonism was charged with responsibility for the Arian heresy. The heterodoxy of the most Platonising of the Church Fathers, Origen, was attributed to his Platonism. The correlation between Platonism and religious heterodoxy re-surfaces in the seventeenth century with the rise of a new forms of anti-Trinitarianism, especially Socinianism. At the same time, in England there was a revival of Origen, especially among anti-Calvinist thinkers associated with the University of Cambridge - prominent among whom were Cudworth and More. ${ }^{15}$ This development was not welcomed after the Restoration of the monarchy, when ecclesiastical authority of the Church of England had been re-established, and was attacked as heterodox, most prominently by Samuel Parker in his Free and Impartial Censure of the Platonic Philosophy (1666), directed at these latter day Origenists; i.e., the Cambridge Platonists.

More considered that Christianity was a rational religion ("I conceive the Christian Religion rational throughout" $)^{16}$ but not at the expense of revelation. It is, he writes, the "special Prerogative" of Christianity that "it dares to appeal unto reason."17 Initially, More valued Cartesianism as a major source for the rational defence of religion, and he drew a parallel between his own intentions and those of Descartes:

tion of Cartesianism. See Sarah Hutton, "Cartesianism in Britain," in The Oxford Handbook of Cartesianism, ed. Steven Nadler and Tad Schmalz (Oxford, 2019), 496-513.

15 For the historical background and relevant literature, see Rhodri Lewis, "Of 'Origenian Platonisme': Joseph Glanvill on the Pre-existence of Souls," Huntington Library Quarterly 69, (2006), 267-30o. See also Sarah Hutton, "Anne Conway and Henry More on Preexistence and Universal Salvation," in "Mind Senior to the World": Stoicismo e origenismo nella filosofia platonica del seicento inglese, ed. M. Baldi (Milan, 1996), 113-125.

16 More, $\operatorname{csp} W$ (see above n. 10), Preface, sect.iv.

17 Ibid., v. 
We both setting out from the same Lists, though taking several wayes, the one travailing in the lower Rode of Democritisme, amidst the thick dust of Atoms and flying particles of Matter, the other tracing it over the high and aiery Hills of Platonisme, in that more thin and subtil Region of Immateriality, meet together at the same Goale, namely at the Enterance of the holy Bible, dedicating our joynt labours to the use and glory of the Christian Church. ${ }^{18}$

In his Epistola H. Mori ad V.C., for example, More defends Descartes's religious credentials - asserting the conformity of Cartesian physics with the Genesis account of creation, and that Descartes' demonstration of the existence of God is the best that human reason can devise. ${ }^{19}$ But More would later backtrack on his initially favourable view of Cartesianism. Although he continued to hold that Descartes was not himself an atheist, he came to think that Cartesian philosophy was a threat to religion, because it ascribed too much to the motion of matter and failed to demonstrate the whereabouts of the soul.

More's reappraisal of Descartes may be correlated with external factors. One was the growing perception that Descartes had opened the way for others to propose materialist philosophies, the most notorious examples being Hobbes and Spinoza. ${ }^{20}$ But even before this, during the 166 os there was pressure on More on account of his religious views. In particular his publicly expressed admiration for Origen, and his subscription to the heterodox doctrine of the pre-existence of the soul were not viewed favourably by the new Church of England authorities.

Pre-existence of the soul was a doctrine to which More subscribed throughout his career, from his Philosophical Poems of 1647 to the Preface to his last published work, his Opera omnia of 1687 . His reasons were both theological and philosophical: to counter Calvinist determinism with a positive view of the deity and to defend the immortality of the soul against the materialists of his day, especially Hobbes. The doctrine of pre-existence was integral to his conception of the soul's immortality and the over-riding goodness of God. ${ }^{21}$

18 Ibid., iv.

19 Epistola H. Mori ad V.C. quce apologiam complectitur pro Cartesio, quceque introductionis loco esse poterit ad universam philosophiam Cartesianam. This was first published in More CSPW in 1662, and printed separately in 1664. From 1669 it was appended to editions of More's Enchiridion ethicum.

20 Alan Gabbey, "Philosophia Cartesiana Triumphata: Henry More (1646-1671)," in Problems in Cartesianism, ed. T.M. Lennon et al. (Kingston \& Montreal, 1982), 171-250.

21 On More and pre-existence see Robert Crocker, Henry More, 1614-1687 (Dordrecht, 2003), 111-125; Sarah Hutton, "Anne Conway and Henry More on Preexistence and Universal Sal- 
In the 1640 , More does not seem to have needed to defend his admiration for Origen. This was perhaps because he wrote in verse. Or perhaps because, in the absence of ecclesiastical censorship, it was a period when heterodox views of many kinds were being aired. It seems to have been only after the Restoration that he felt the need to defend his position. Given Origen's heterodoxy, it is not surprising that More had his detractors in the Anglican Church establishment of the post-Restoration. Central to their objections was the doctrine of the pre-existence of the soul. ${ }^{22}$ Faced with censorship by the church authorities, More eventually reached a compromise: he would only refer to the doctrine as a hypothesis, not a truth. He nevertheless continued to recommend it on philosophical grounds, for instance, by means of the causal theory which he proposed to compensate for the shortcomings of Descartes's mechanistic physics, his hypothesis of the Spirit of Nature, one of whose functions is to prepare matter to receive pre-existent souls and to guide them to their bodies. While there is no direct link between his subscription to pre-existence and either his acceptance or rejection of Cartesianism, it is more than likely that he felt it necessary to dissociate his own philosophy from association with other philosophies which might be deemed to threaten religion.

\section{5}

\section{Cudworth}

Cudworth's major work, The True Intellectual System of the Universe is a massive exercise in religious apologetics, consisting in large part of consensus gentium arguments for belief in God. A sustaining motif in Cudworth's analysis is that errors in philosophy correlate to errors in religion, while true philosophy and right belief in God go together. Among the philosophers whom Cudworth critiques is Descartes. Notwithstanding his admiration for him, and notwithstanding the fact that he did not think Descartes was an atheist, or that he intended to promote atheism, Cudworth had strong reservations about his philosophy. Although he thought that Descartes's philosophy is necessarily the-

vation," in "Mind Senior to the World": Stoicism e origenismo nella filosofia platonica del seicento inglese, ed. M. Baldi (Milan, 1996), 113-125; Jasper Reid, The Metaphysics of Henry More (Dordrecht, 2012), 349-356.

22 On the suspicion in which Cudworth More was held by hard-line Calvinists in the 1640s and by the Anglican establishment in the 166os, see my "A Radical Review of Cambridge Platonism," in Varieties of Seventeenth- and Early Eighteenth-Century English Radicalism, ed. Ariel Hessayon and David Finnegan (Farnham, 2011), 161-182. See also Hutton, "Ralph Cudworth's Sermon Before the House of Commons in Theological and Political Context," Adamantiana, 11 (2019), 35-49. 
istic, since a central claim of his metaphysics that body is extension requires us to posit some kind of immaterial principle of activity to account for movement, ${ }^{23}$ he nevertheless concluded that flaws in Descartes's arguments made him a "well-wisher" to atheism, or even "an Hypocritical Theist, or Personated and Disguised Atheist." ${ }^{24}$ The root problem, for Cudworth, was Descartes's conception of divine will. Cudworth interprets Descartes as a voluntarist, whose conception of the divine will is akin to Calvinism because he overplays divine will and power to the detriment of all truth and goodness. Descartes's voluntarist conception of divine will, and his identifying free will with indifference of will renders truth and goodness arbitrary (literally so) since God may freely determine the nature of truth and goodness purely by the power of his will. This amounts to scepticism by another name. Unpersuaded by Descartes's metaphysical proofs for the existence of God, Cudworth argued that their shortcoming would be less serious but for Descartes's repudiation of final causes. By rejecting final causality, Descartes has undermined the well-tested argument from design and "quite disarmed the World, of that grand Argument for a Deity, taken from the Regular Frame and Harmony of the Universe." In this way, he has out-done "even the very Atheists themselves." ${ }^{25}$ Cudworth proposed his hypothesis of 'Plastick Nature' in part to address the problem of lack of final causality in Descartes's mechanistic account of the workings of nature.

If Descartes failed to meet the criteria of a philosophical defence of religion, a group of philosophers whom Cudworth considered useful for defending the truth of religion were the Platonists, who figure prominently in Cudworth's extensive discussion of the Trinity. Supporting his views with extensive erudition (which, at that time favoured the now discredited idea that Plato had a conception of Trinity), he argued that Plato's version of it was remarkably close to the Christian conception-so much so that there does not seem "to be so great a Difference, betwixt the more Genuine Platonists, and the ancient Orthodox Fathers, in their Doctrine concerning the Trinity."26 While conceding that many Platonists, especially later Platonists like Porphyry, had misinterpreted the Trinity and introduced heretical corruptions, ${ }^{27}$ he argued that the "True and Genuine" Platonic Trinity (as opposed to the "Spurious and Adulterated" Trinity of the "Junior Platonists") accorded with "the Generality of the Chris-

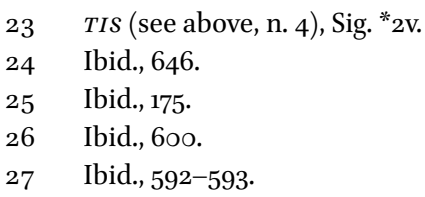


tian Fathers, before and after the Nicene Council, [who] represent the Genuine, Platonick Trinity, as really the same thing with the Christian." ${ }^{28}$

While Cudworth was careful to insist that "our Belief of the Holy Trinity, is Founded upon no Pagan Cabbala's, but onely Scripture Revelation," he nevertheless argued for a charitable interpretation of the Platonic Trinity which emphasised its similarities with Christian version, rather its differences from it. It is, he claims

rather to be wondred at, that living so long before Christianity, as some of them did, they should in so Abstruse a Point, and Dark a Mystery, make so near an approach to the Christian Truth afterwards revealed, than that they should any where fumble or fall short of the Accuracy thereof. ${ }^{29}$

The usefulness of Plato's supposed grasp of the Trinity for apologetic purposes is that Plato was a respectable philosopher who could grasp a mystery without the help of revelation. So instead of the Trinity being an obstacle to persuading libertines and doubters ("the Choak-Pear of Christianity"), they might be persuaded of its truth

when they shall find, that the Freest Wits amongst the Pagans, and the Best Philosophers, who had nothing of Superstition, to Determine them that way, were so far from being shy of such an Hypothesis, as that they were even Fond thereof. ${ }^{30}$

Leaving aside the fact that Cudworth's argument depends on out-dated scholarship, this argument is less likely to appeal to downright atheists than to lukewarm believers ("Weak, Staggering, and Scepticall Theists"). And, whether or not we share Cudworth's confidence that the latter might be won over by the example of Plato, this defence of Christian belief came at a cost. Although he acknowledges that the Platonic Trinity differs from "the Now-received Doctrine in the Christian Church,"31 the parallel which he attempts to draw with the Christian Trinity depends on a subordinationist view of the latter:

\begin{tabular}{ll}
\hline 28 & Ibid., 621. \\
29 & Ibid., 595. \\
30 & Ibid., sig. **2v. \\
31 & Ibid., 592.
\end{tabular}


[A]ccording to the Principles of Christianity it self, there must of necessity, be some Dependence and Subordination of the Persons of the Trinity, in their Relation to one another; a Priority and Posteriority. ${ }^{32}$

The thanks which Cudworth received for his pains in sorting out atheistic philosophy from theistic philosophy was to earn himself a reputation for atheism and heterodoxy. The poet John Dryden claimed that when presenting the arguments of the atheists, "Cudworth raised such strong objections against the being of a God and providence, that they think he has not answered them." 33 Another reason for hostility towards Ralph Cudworth's True Intellectual System was his discussion of the doctrine of the Trinity, and this makes him a key reference point in the Unitarian Controversy of the 169os. ${ }^{34}$ If Cudworth's doctrine of Plastic Nature can be defended against the charge of incipient atheism, Cudworth's appeal to Plato as a guide to the Trinity is hard to defend against the charge that he was a secret Arian.

Anne Conway, like Cudworth, sought to separate out the best from the worst in both the philosophy of ancients as well as that of her contemporaries. Like Cudworth, she also held that errors in philosophy result in misperceptions about God, with damaging consequences for religious belief, or "true piety" (pietatis verae), as she puts it. At the heart of Conway's critique of contemporary philosophy in her Principles of the Most Ancient and Modern Philosophy (1690) is her rational conviction that the positing of material substance, as distinct from spiritual substance, and a mechanistic view of the operations of nature, is "an absurd foundation," from which

many crass and dangerous errors have arisen, not only in philosophy, but also in theology (so called) with great injury to the human race, to the great detriment of true piety and contempt of the most glorious name of God, as will easily appear, both from what has been already said, as from what will be said in this Chapter. ${ }^{35}$

$32 \quad$ Ibid., 598.

33 Dryden, "Preface to Virgil Aeneid vol. 2," cited in Birch's Preface to TIS (1743), xiii.

34 Philip Dixon, Nice and Hot Disputes: the Doctrine of the Trinity in the Seventeenth Century (London, 2003). This is also known as the Trinitarian controversy.

35 Anne Conway, The Principles of the Most Ancient and Modern Philosophy, translated by Allison P. Coudert and Taylor Corse (Cambridge, 1996), 63. 
Conway does, however, give Descartes credit for acknowledging that God is an immaterial being, unlike Hobbes and Spinoza. She also critiques Spinoza's pantheism which "confounds God and the creatures, and makes one being of both." ${ }^{36}$ The root error common in all three is their misconception of matter as lifeless extension. As a result, they miss the essential and "excellent" nature of created substance:

[T] hey do not go beyond the husk or shell, nor ever reach the kernel. They only touch the surface, never glimpsing the center. For they ignore the noblest and most excellent attribute of that substance, which they call body and matter, and understand nothing about it. ${ }^{37}$

This excellent attribute is life,

by which I mean a capacity of all kind of feeling, sense, or knowledge, even love, power and virtue, and all joy and fruition which the noblest creatures have or can have; even the vilest and most contemptible. Even dust and sand, may be capable of all those perfections. ${ }^{38}$

Conway instead sought to formulate a philosophy consistent with the truth of religion. Accordingly, she sets out a teleological account of nature consistent with her conception of a God as a providential, loving being, which is lacking in the philosophies she critiqued. Accepting the similarity principle that all things must be like their cause, she argues that all things resemble God. So, God being spirit, all things are modes of spirit-hence the substance monism of created things. Likewise, all things possess life, and God being loving and just, they must be capable of perfectibility. This squares with her religious belief in God as a "loving father" and not a "cruel tyrant," who works to save all created beings.

Anne Conway's ontology of three species might be just another Neoplatonic system deduced from a first cause conceived in a particular way. But her treatise is so structured as to bring religion and philosophy into alignment. Conway maps out her system using theological terms (the three species are named God, Christ, and Creature), and the over-all schema fits onto a Christian framework of sin and redemption. This is not accidental, but founded on a deep conviction that religious truth is accessible to reason and motivated by a strong desire

36 Ibid., 64.

37 Ibid., 28.

38 Ibid. 
to underscore the core of truth common to Judaism, Islam, and Christianity as well as the compatibility of philosophy with religious truth. As this suggests, there is more to Conway's text than merely adopting Christian terminology. She makes interventions in her text which depart radically from orthodox doctrine, denying the existence of hell and positing universal salvation. She also reconceptualises the Trinity, arguing on both rational and scriptural grounds that "the phrase concerning the three distinct persons ... is a stumbling block and offense to Jews, Turks, and other people."39 Although she recognises the divinity of Christ, she construes the second and third persons of the Trinity as the wisdom and the will subsumed under the godhead:

Wisdom and will in God are not entities or substances distinct from him but, in fact, distinct modes or properties of one and the same substance. And this is that very thing which those who are the most knowledgeable and judicious among Christians understand by the Trinity. ${ }^{40}$

Central to Anne Conway's system is her theory of universal redemptionwhich she understands in both an ontological and a moral sense. God being "charity and kindness itself," it is entirely inconsistent for him with His nature to punish arbitrarily or disproportionately. The purpose of punishment is to further the end of redemption:

[A]ll degrees and all kinds of sin have their appropriate punishments, and all these punishments tend toward the good of the creatures, so that the grace of God will prevail over judgment and judgment turn into victory for the salvation and restoration of the creatures. ${ }^{41}$

All these heterodox views contain clear echoes of Origen, as may be gauged from a comparison with the anonymous Origenist text, attributed to George Rust: A Letter of Resolution Concerning Origen and the Chief of His Opinions (1661). The "chief opinions" discussed in this are the hypostasised Trinity, the pre-existence of souls, the corporeality of fallen souls, the incorporeality of the redeemed, universal salvation, and the doctrine of periodic renewal-a close match with Conway. But Conway's heterodoxy extends far beyond her debt to Origen because her system has radical implications for the relative status of human beings to one another, and also of human beings to other natural

39 Ibid., 10.

$40 \quad$ Ibid.

41 Ibid., 37. 
kinds. Since, metaphysically, regeneration is possible for everything and not just for human beings, and since she holds that in this process all creatures inter-mutate, human beings and all natural kinds are integrally inter-related. And, since every aspect of nature is alive, good, and perfectible, human beings are not unique in possessing souls which are uniquely the subject of moral law. All things in nature are subject to God's justice, and beneficiary of his love.

\section{$7 \quad$ Conclusion}

The philosophies of More, Cudworth, and Conway illustrate the difficulties of bringing philosophy into alignment with religion. Their respective critiques of Descartes show they were discriminating in their choice of the philosophy which they took to be compatible with Christian belief. But there is no question of the heterodoxy of some of the doctrines which they espoused and that they held these to be philosophically defensible. Clearly, in their case, their heterodoxy was not intentionally a step in the direction of atheism. It is an open question as to whether their heterodox views were necessary adjustments in their beliefs in order to sustain that compatibility. 